\title{
Peacebuilding in a Conflict-Torn North-Eastern Nigerian Society: Going Beyond Reconstructive Peacebuilding
}

\author{
Philip Onyinye Egbusie \& Modupe Oluremi Albert \\ Department of Politics and International Relations, Lead City University, Ibadan, Nigeria
}

\begin{abstract}
Members of the Boko Haram sect have a preference for the Arabic name Jama'atu Ahlis Sunna Lidda'awati Wal-Jihad which means "People committed to the propagation of the Prophet's Teachings and Jihad". This insurgent group is alleged to have been founded in Maiduguri, the capital city of Borno State, in the North East of Nigeria. It is however argued that the sect is one of the bloodiest militant groups in the world which has continuously targeted both civilian and non-civilian citizens and has constantly inflicted devastating mayhem on the people of the north-eastern Nigeria. With over a decade-long of conflict in that region and its devastating effects in terms of loss of human lives, destruction of properties and infrastructure as well as economic loss, one then begins to doubt the possibility, certainty, practicability, and efficiency of peacebuilding in that conflicttorn society. This paper thus proposes a more tactical and pragmatic approach towards peacebuilding in a conflict-torn society by going beyond reconstructive peacebuilding,
\end{abstract}

Keywords: Peacebuilding, Post-conflict Reconstruction, Reconstructive Peacebuilding.

\section{INTRODUCTION}

$\mathrm{H}$ ouses have been razed by fire; schools, churches and mosques have been destroyed; some villages once occupied have now become ghost lands and families have been torn apart. Men, young and old have been killed; Christians and Muslims alike butchered. Women and girls have been raped, sexually violated and exploited, and many taken into captivity. Some, under duress have renounced their faith and those who refused to, have remained in captivity for years; others either sold into slavery or forced into marriages and thousands in precarity. With tens of thousands killed and over two million internally displaced, the pains of this agony are real, the ravages of the ongoing insurgency still bits deep into the flesh of not only the victims, but of the whole nation.

After more than a decade of conflict in Nigeria's north eastern region, and its severe human, infrastructure, and economic loss, one begins to doubt the possibility, certainty, practicability, and efficiency of peacebuilding in that conflicttorn society. This paper is set to propose a more tactical and pragmatic approach to peacebuilding in a conflict-torn society, such as the situation in Nigeria's North-Eastern region, by going beyond reconstructive peacebuilding which will be discussed under the following headings: a background of the Boko Haram insurgency in Nigeria; Boko Haram activities in north-eastern Nigeria; understanding the concept of peacebuilding; post-conflict reconstruction; beyond reconstructive peacebuilding; and finally, recommendations will be made.

\section{The Boko Haram Insurgency in Nigeria}

Members of the Boko Haram sect prefer the Arabic name Jama'atu Ahlis Sunna Lidda'awati Wal-Jihad, which means "People committed to the spread of the Prophet's Teachings and Jihad," according to Oluwatosin (2016). This insurgent group is said to have started in Maiduguri, the capital of Borno State in Nigeria's north east. According to Diyoke and Oguche (2019), the name "Boko Haram" is a mix of the Hausa word "book," which implies "Western education," and the Arabic word "haram," which means "forbidden," implying that Western education is prohibited.

However, it is argued that this sect is one of the most bloodthirsty militant groups, having repeatedly targeted both civilians and non-civilian citizens, and inflicted devastating mayhem on the people of North Eastern Nigeria. Furthermore, it is speculated that the group began in 1995 under the aegis of the al-Shabaab terrorist organisation (Adesina, 2013). The Boko Haram sect, which was founded on the Khawaarij beliefs, has called for the implementation of Sharia law. In 2009 , it morphed into a Jihadist organisation. Their views are firmly established and oriented on rigorous devotion to Wahhibism, an exceedingly rigid type of Islam that considers many other forms of Islam to be idolatrous (Onuoha, 2014), and has labelled members of the Sufi, Shiite, and Izala sects of Islam as infidels (Ogunlesi, 2015). Boko Haram's founder, Mohammed Yusuf, was trained by Kano Salafi Izala Sheik Ja'afar Mahmud Adamu, who referred to him as a "leader of young people"; nonetheless, the two had their differences in ideologies sometime between 2002 and 2004. Yusuf, who has been labelled as well-educated by experts, restated his hostility to Western education in a 2009 BBC interview. He denied evolution, claiming that rain is not an "evaporation driven by the sun" and that the Earth is not a sphere.

Mohammed Yusuf founded a religious complex and school in 2002 that drew poor Muslim families from all around Nigeria and neighbouring nations. The center's political purpose was to establish an Islamic state, and it became a hotbed for jihadist recruitment. Yusuf drew support from unemployed youngsters by exposing police and state corruption (Chothia, 
2012). According to some reports, Yusuf established Boko Haram because he saw an opportunity to capitalise on public fury over government corruption by tying it to Western influence in governance (The Guardian Newspaper, 2009).

Yusuf is said to have recruited followers using the Izala Society's existing infrastructure in Borno (Jama'at Izalatil Bidiawa Iqamatus Sunnah), a popular conservative Islamic sect, before splitting off to start his own faction. The Izala, as well as those sympathetic to Yusuf, were initially welcomed into government. During the first seven years of its existence, Boko Haram operated more or less peacefully, withdrawing from society into rural north-eastern territories. The Nigerian government has frequently disregarded warnings about the organization's growing militant nature (The Independent, 2009). The Federal Government and the Nigerian Television Authority were warned not to broadcast Yusuf's sermons by the Council of Ulama (the Kingdom of Saudi Arabia's highest religious authority, which advises the king on religious matters), but their warnings were ignored (Adesoji, 2010).

The Nigerian Police Force launched an investigation into the gang known as Operation Flush in 2008. Security forces apprehended nine Boko Haram terrorists on July $26^{\text {th }}$ and seized firearms and bomb-making materials. It has been reported that a clash with police officers during a funeral procession, resulted in police retaliation and widespread rioting. In response, a joint military task force operation was begun, and by the $30^{\text {th }}$ of July, more than 700 individuals had been murdered; majority of them were Boko Haram militants. Police stations, jails, government offices, schools, and churches had been demolished (Al Jazeera, 2010). Yusuf was apprehended by the Nigerian Police Fore but died while in police custody.

Boko Haram, having reassembled under its new commander, broke 105 of its members out of a prison in Bauchi, along with roughly 600 other inmates in September 2010, and then began coordinated attacks in many locations of the country's northern region. The group's operational capabilities have been steadily upgraded under Shekau's command (Mshelizza, 2011). After a series of improvised explosive device (IED) attacks against vulnerable targets, including its first vehicleborne IED attack in June 2011, which killed six people at the Abuja police headquarters, Boko Haram attacked the United Nations (UN) headquarters in Abuja in August of that same year. A spokesman for the terrorist group announced that the group claimed responsibility for the attack on the UN headquarters which killed $11 \mathrm{UN}$ staff members and injured more than 100 others, and warned of further strikes against the United States and Nigerian government's facilities. He went on to reveal Boko Haram's terms for discussion, which included the unconditional release of all its imprisoned members. Analysts thus began to speculate that Boko Haram was associated with Al-Qaeda in the Islamic Maghreb (AQIM), which was active in Niger Republic, because of the group's improved sophistication (Cook, 2011).
Since 2011, Boko Haram has maintained a consistent tempo of attacks, hitting a wide range of targets numerous times per week. Politicians, religious leaders, security personnel, and civilians have all been targeted. The suicide bombing strategy utilised in the two attacks on the police and the UN offices in Abuja was the first of its type in Nigeria. It had only been utilised by al-Shabaab in Somalia and to a lesser extent by AQIM in Africa as a whole (Adetayo, 2012).

Boko Haram carried out a series of bomb attacks in Bauchi, Zaria, and Abuja few hours after Goodluck Jonathan's presidential inauguration in May 2011. The attack on the army barracks in Bauchi was the most successful of these. According to a spokesman for the group, the attack was carried out as a test of allegiance by serving military men who wanted to join the group. The Nigerian Army later refuted this report, claiming that the army had not been compromised.

According to Gardham and Heaton (2011), on January $8^{\text {th }}$ 2012, the president declared that Boko Haram had infiltrated the Nigerian Army and Police Force, as well as the executive, parliamentary, and legislative arms of government. Furthermore, Boko Haram claimed responsibility for the assassination of Abba Anas Ibn Umar Garbai, the younger brother of the Shehu of Borno and the country's second most senior Muslim personality after the Sultan of Sokoto, outside his Maiduguri residence. A statement from the group read thus: "We are doing what we are doing to fight injustice and we would stop what we are doing if they stopped their satanic methods of doing things and the injustices" (Gardham \& Heaton, 2011). Boko Haram carried out a number of political and religious assassinations in that year' ostensibly, to remedy injustices in the group's native state of Borno. Meanwhile, the bloodshed raged unabated, threatening to plunge the country into civil war.

The defeat of Muhammadu Buhari in the 2011 presidential election heightened ethnic, religious, and political tensions, as it violated an unspoken agreement that the office of the president would rotate every two terms between candidates from the country's Christian south and Muslim north. During the three days following the election, sectarian riots engulfed the country's twelve northern states, claiming the lives of over 800 people and displacing 65,000. Boko Haram's ensuing campaign of violence culminated on Christmas Day 2011 with a series of explosions around the country. On the outskirts of Abuja, 37 people were killed when the roof of a church was blown off. On New Year's Eve of 2011, Jonathan announced a state of emergency in the Jos, Borno, Yobe, and Niger states, as well as the closure of the international border in the north-east (Ewi, 2013).

In 2011, Boko Haram perpetrated 115 attacks, killing 550 people. The declaration of a state of emergency resulted in an increase in violence. More than half of the deaths for the previous year occurred in the first three weeks of 2012. According to Mshelizza (2011), Boko Haram issued an ultimatum to southern Nigerians living in the north two days after the state of emergency was announced, giving them three 
days to evacuate the northern region of the country. A wave of attacks on Christians and members of the Igbo ethnic group occurred three days later, causing hundreds of people to escape. On the $20^{\text {th }}$ of January 2012 , the group carried out by deadly assaults on police buildings in Kano, killing 190 people. Car bombs, suicide bombers, and IEDs were used in these attacks, which were backed up by uniformed gunmen.

The kidnapping of 276 schoolgirls from a secondary school in Chibok, Borno State, in April 2014, was one of Boko Haram's most high-profile atrocities, drawing international attention to the group. Boko Haram's commander, Abubakar Shekau, pledged allegiance to the Islamic State of Iraq and the Levant (ISIL) on March 7, 2015, renaming the group Islamic State in West Africa (ISWA). Although Boko Haram's main base of operations is in Nigeria, the insurgency's impacts have been felt not just in Nigeria, but also in the countries that border the country (Cook, 2011).

\section{Boko Haram Activities in North-Eastern Nigeria}

In May 2014, barely a month after the Chibok school incident, Boko Haram terrorists again, attacked the towns of Gamboru and Ngala in Borno State, north-eastern Nigeria. According to sources, the attack which lasted for about twelve hours, claimed the lives of about 310 residents, the abduction of 11 teenage girls and the destruction of both towns (Ford, et. al., 2014).

Similarly, between the $3^{\text {rd }}$ to $7^{\text {th }}$ of January, 2015, Boko Haram terrorists launched a gruesome attack on the town of Baga, Borno State. The attack which began on the $3^{\text {rd }}$ occurred when the terrorists besieged a military base that was the headquarters of the Multinational Joint Task Force (MJTF) holding troops from Chad, Niger, and Nigeria. The extent of the killings remains unknown. It is reported that the exact death toll in Baga and 16 other neighbouring villages is unknown, with estimates of over 2000 people (Mausi, 2015). In July 2015, Boko Haram fighters again struck. This time around, they attacked the village of Kukawa, a north-eastern village near Lake Chad. The attack which occurred on the $1^{\text {st }}$ of July, claimed about 150 lives. According to eyewitnesses, the terrorists besieged Kukawa in the evening of Wednesday, $1^{\text {st }}$ July, 2015 and killed 97 people, women and children inclusive. It is reported that more than 50 Boko Haram fighters invaded Kukawa killing men in various mosques who were observing the Maghrib prayer shortly after breaking their Ramadan Fast. The previous day, $30^{\text {th }}$ June, the terrorists had killed 48 men who had just finished Maghrib prayer in two villages near the town of Monguno. (Nossiter, 2015).

In January 2020, Chad withdrew its troops from Nigerian who were part of the MJTF, a regional initiative established to counter the Boko Haram terrorism in the region. In Adamawa state, on the $20^{\text {th }}$ of January of the same year, the terrorists beheaded a Christian who had been abducted in Micika, Reverend Lawan Andimi. That same month, Daciya Dalep, a 22-year-old student, was executed by a child soldier who was a member of the terrorist group (Amnesty International, 2020).

About 30 civilians were burnt to death in February, 2020 by Boko Haram fighters when they attacked travellers on their way to Maiduguri who had made a stop-over at Auno, Borno State (BBC, February 2020). In March 2020, at least 50 soldiers were killed in a Boko Haram ambush in Yobe state. Boko Haram continued to commit grave human rights abuses in the north-east, including killings and abductions of civilians, which amounted to war crimes and may have constituted crimes against humanity. More than 420 civilians died in around 45 attacks, many of them in Borno state, but also in Adamawa and Yobe. Meanwhile, Boko Haram continued to recruit child soldiers. In June 2020, 81 people were killed and several others abducted during an attack on the village of Faduma Kolomdi. In October, some 20 farmers were killed in Boko Haram attacks in the villages of Ngwom and Moromti. Throughout the year, Boko Haram abducted hundreds of women and girls and subjected them to rape and forced marriage, including 20 who were taken in July when they were searching for firewood near the Gamboru internally displaced people's camp in Borno state (Amnesty International, 2020).

On the $28^{\text {th }}$ of November 2020, Boko Haram insurgents reportedly attacked a farming community in Jere Local Gogernment Area, Borno State, killing about 110 people including farmers who were working on their rice farms. The attackers who were on motorbikes, rounded-up their victims and tied them up before slitting their throats (Sani, 2020). This attack came days after a gunman, who was a member of Boko Haram group came to harass the farmers by ordering them to give him money and also cook for him. While he was waiting for the food to be prepared, the farmers utilized the opportunity when the gunman went into the toilet to get his rifle and tied him up. These brave farmers handed him over to the security operatives who unfortunately, were unable to protect the farmers. A reprisal for daring them was launched by the terrorists who mobilised themselves and attacked the community on the $28^{\text {th }}$ on November. The terrorists further burnt down rice farms before leaving (News Wires, 2020). These are just a few of the heinous atrocities perpetuated by Boko Haram terrorists in some north-eastern communities in Nigeria.

\section{Understanding the Concept of Peacebuilding}

In 1992, the then UN Secretary General, Boutros-Ghali presented his "Agenda for Peace". It was at this time that the term "peacebuilding" came into use. As a result, peacebuilding has become a widely used but frequently illdefined word that refers to activities other than crisis assistance, such as long-term development and the construction of governmental and other institutions (Albert, 2001).

Bolarinwa (2006) opines that the ability of non-governmental organisations for peacemaking and peacebuilding is included 
in peacebuilding. The United Nations has always stressed structural change, with a particular emphasis on institutional reform in its process of peacebuilding. Nonetheless, peacebuilding entails a wide range of tactics, processes, and phases for transforming relationships and governing modes along with institutions by making them more sustainable and peaceful. Building legal and human rights institutions, as well as fair and effective governance and conflict resolution processes and mechanisms, are all part of peacebuilding. Peacebuilding activities require careful and participatory planning, coordination of multiple efforts, and unwavering pledges from all parties to be effective (Bolarinwa, 2006).

As a result, peacebuilding necessitates a long-term commitment to a process that comprises investment, resource collection and planning, architectural and planning, resource coordination and labour, laying solid foundations, construction of infrastructures and so on and their continuous maintenance. However, interpersonal transformation is at the heart of peacebuilding. Both structural and relational restructuring are required for long-term reconciliation (Durojaiye, 2010). According to Aiyede (2006), the concept of peacebuilding gained clarity and coherence in 1992 when it was defined as "action to identify and support structures that will tend to strengthen and solidify peace in order to avoid a relapse into conflict, and the rebuilding of institutions and infrastructure of nations damaged by civil war and strife deepest causes of conflict: economic despair, social injustice, and political oppression."

Understanding efforts that promote long-term stability and fairness has also been termed as peacebuilding. It aims to achieve peace-enhancing results by paying close attention to the procedures and outcomes (Gandhi, 2007). Furthermore, peacebuilding is one of the actions in intervening in conflict with the goal of resolving the root cause of conflict development. This can primarily be carried out by the government, civil society (non-governmental organisations), international organizations, or individuals. This begins by engaging in a conversation process with the conflict's actors. In Lederach (1995) view, this can be done at any moment, as long as the positive and negative goals of conflict intervention are met; it can take place anywhere, not only at a round table discussion with everyone present at the same time. It has advantages for all conflict parties as well as other stakeholders.

Aderigbigbe (2010) argues that peacebuilding entails topics such as reconciliation, reconstruction, and rehabilitation, among others. Reconciliation creates a space for combatants and displaced people to vent their sorrows and agony, as well as address the root causes of conflict and promote mutual cooperation via justice, truth, mercy, and forgiveness. In most circumstances, the parties to the conflict will need to see some prospects in the entire reconciliation process before they consent. Thus, making reconciliation a challenging undertaking in peacebuilding. Internal reconciliation, on the other hand, has received less attention in various literatures in international relations and peace and conflict studies as a component of peacebuilding (Aderigbigbe, 2010).

Furthermore, the reconciliation procedure includes determining whether the offended party has any valid claims. Truth, justice, kindness, and peace are the four basic parts of the reconciliation process. Reconstruction provides a "second chance" for post-war societies to reform by restoring social infrastructures that were destroyed as a result of the conflict. A conflict scenario can be regenerated by a lack of basic social facilities. As a result, many efforts should be made to create a vibrant post-conflict society (Ghali, 1992). Finally, rehabilitation is a process that allows internally displaced people, refugees, and ex-combatants to reintegrate and demobilise by providing strategic peacebuilding measures such as job opportunities, creative and vocational skill development, psychological trauma-healing, advice and support (Aderigbigbe, 2010).

In most cases, the immediate post-conflict period is marked by instability and political uncertainty. As a result, the process of returning to peace is likely to progress, but it frequently regresses. Many countries are governed by transitional political arrangements during this time, until after the first post-conflict elections, when duly and newly elected persons resume executive and legislative powers. As a result, the effectiveness of peacebuilding is dependent in part on peopleinvolved political decision-making, effective leadership by national governments the United Nations, and other resources such as human capital and donor funding (Galtung, 1996). The peacebuilding process is essentially a national obligation and challenge. Citizens of nations where peacebuilding is taking place, with the help of their governments, who are taking on the responsibility, are critical stakeholders in laying the groundwork for long-term peace. Consequently, a strong sense of national ownership is essential for success.

National capacity development must be at the forefront of all international peacebuilding initiatives from the beginning, as part of the entry strategy rather than the exit plan. Indeed, one of the most important goals of peacebuilding is to get to the point where no external aid is needed as soon as possible, by ensuring that all activities support the development of national peacebuilding capacities. This is a difficult task, especially in the early stages of peacebuilding when national capacity is frequently relocated and severely curtailed. Peacebuilding, on the other hand, must prioritise the restoration of national capability; otherwise, peace will not be sustainable (Aderigbigbe, 2010).

\section{Post-conflict Reconstruction and Peacebuilding}

Aderigbigbe (2010) contends that post-conflict reconstruction is a critical feature of the peacebuilding process, particularly in nations where violent wars have recently concluded. It entails reconciliation, development, and programmes involving all citizens, all of which are required for a holistic healing process. In a country that has recently experienced widespread violence, or where the state's primary concern is 
armed warfare, or where a significant portion of the population is engaged in armed conflict with the state, this process typically entails the repair and reconstruction of physical and economic infrastructure. In a post-conflict situation, state institutions are frequently so weakened that they only have a limited capacity to fulfil their responsibilities. As a result, post-conflict reconstruction necessitates a variety of external interventions aimed at restoring weakened institutions. Revamping the economy, restructuring the framework for democratic governance, rebuilding and maintaining key social infrastructure, and planning for financial normalisation are among the critical interventions (Aderigbigbe, 2010).

Supporting the transition from war to peace, resuming economic and social development, reconciliation and reconstruction, human and institutional capacity building, and establishing special investment funds to maintain social cohesion during the period of economic adjustment, and poverty reduction and decentralisation are all common goals of post-conflict intervention (Adekanye, 1997). It is therefore clear that post-conflict reconstruction activities need to be thoroughly scrutinised in order to maintain their value, efficacy, and competence. However, it is suggested that the entire reconstruction process in a post-conflict society should be viewed as a multi-faceted one, with military, political, psychosocial, humanitarian, and economic components all intertwined. Furthermore, Adekanye (1997) claims that if post-conflict reconstructions are not implemented effectively and all stakeholders are not adequately reintegrated into the state (in the post-conflict era), a return to war is a possibility.

The implications for the stability and long-term development of emerging post-conflict societies have aroused the interest of academics and policymakers in demilitarisation, democratisation, economic reconstruction, and structural adjustment, as well as the reduction of defence expenditures to supportable levels, demobilisation, reintegration, and rehabilitation of ex-combatants. It is argued that specific concerns could be identified as pivotal in a post-conflict environment on a global scale because there are empirical interconnections between the conflict stage and the postconflict stage, between violence and politics, and between war and peace that should not be overlooked. The contradiction of three transitions in one; reintegration of ex-combatants; problems of illegal arms; power-sharing versus political inclusion; making committed electoral players out of former guerrilla leaders; reconciliation versus justice; economic driven liberalisation versus post-conflict peace building; countering the phenomenon of "return wars" are all important issues that are relevant to the peace process (Adekanye, 1997).

Peace and security are the most significant considerations in planning for long-term development during post-conflict reconstruction, as development contributes equally to longterm peace. The importance of the peace goal has another important implication: the significance of welcoming the political environment and the sensitivity of capacity-building interventions. In terms of the peace process, capacity building is a means to an end of achieving state-run development objectives, plans, and programmes. In addition, in the post-conflict reconstruction process, the development target must be clearly defined, institutional and human resource development must be mapped out, and a capacitybuilding strategy must be properly stated (Kasali, 2006).

At the individual level, it entails enabling people to engage in a lifelong learning process that builds on their existing knowledge and abilities while also expanding them in new directions when new opportunities arise. It also entails institutionally enhancing current capabilities. Rather than attempting to build new and foreign institutions based on foreign blueprints, governments and donors should look for existing initiatives, no matter how small, and encourage them to grow. It involves the capacity within societies as a whole, or their transformation for development, at the societal layer. It includes the enabling process, which is at the heart of human development: the opening and expanding of opportunities that allow people to fully utilise and extend their abilities (Browne, 2002).

\section{Beyond Reconstructive Peacebuilding}

In an attempt to redress the "structural appropriation of reconstruction over transformation in peacebuilding, there is a distinction between reconstructive peacebuilding and transformative peacebuilding. While the one is a creation of the United Nations and peace operations, the other (which is the less widely used form) addresses the causes of conflict and the community level needs of post-conflict societies. Each of these needs to operate in conjunction with the other and peace cannot be attained without addressing both the reconstruction of a community and the transformation of the conflict (Bronwyn, 2001).

In a 2021 study of 250 victims of the Boko Haram insurgency living in internally displaced persons' camps (IDPs), using a Two Way - ANOVA test to determine the effectiveness of reconstructive and transformative peacebuilding processes in the rehabilitation of victims of the Boko Haram insurgency, results showed that reconstructive peacebuilding on its own, had no significant positive impact in the successful rehabilitation of victims of the Boko Haram insurgency as $\mathrm{f}=$ $.066, \mathrm{p}=.997$, hence p>.05 (Egbusie, 2021). The study reinforces the arguments posited by various scholars over the years that reconstructive peacebuilding as the name implies is basically centred and aimed towards only the structural reformation, overhaul, reorganization and reconstruction of a society which has been afflicted and dismayed by protracted tantrum of conflict; consequently, this form of peacebuilding seems to have no long-lasting effect on the victims of conflict who ought to be the foci of peacebuilding.

This is so because reconstructive peacebuilding is a short term structural rebuilding process. The physical and political reconstruction of this form of peacebuilding begins with the United Nations, which has endeavoured to produce a model 
that achieves these outcomes. Reconstructive peacebuilding concerns the more tangible aspects of peace building such as addressing infrastructure needs, the development of healthcare systems and political institutions. On the reconstructive side are activities such as relief, humanitarian assistance, disarmament, demobilization, political restructuring, elections, mine clearance, and health (Bronwyn, 2001).

Nevertheless, Egbusie (2021) in that same study, still using a Two Way - ANOVA test to determine the effectiveness of reconstructive and transformative peacebuilding processes in the rehabilitation of victims of the Boko Haram insurgency, there was a significant positive effect of transformative peacebuilding on the successful rehabilitation of those victims as $\mathrm{f}=.034, \mathrm{p}=.023$, hence $\mathrm{p}<.05$.

In his opinion, transformative peacebuilding on the other hand, is a long term reconciliation. It is a broad term for approaches that focus less on physical reconstruction than on the broader social relationships that exist within conflict-prone societies. It is an attempt to alter conflict such that lasting forms of peace may be built. This form of peacebuilding usually encompasses those aspects that work towards the long term transformation of the conflict environment. They include inter-ethnic contact, contact between professions, stereotype elimination, work collectives, school projects, conflict resolution training, justice, police and military training, crosscultural television and ratio efforts and acknowledgement (Bronwyn, 2001). This form of peacebuilding thus has an integral impact on both the victims as well as the affected society as a whole. It involves a holistic healing process beginning with not only the physical healing of the individual who has been scarred by the warfare, but also the emotional and psychological healing dimensions, which by consequence, promotes the rehabilitation of those who make up the society.

Similarly, in the 2021 study above, the researcher discovered that there was a significant positive joint impact of reconstructive and transformative peacebuilding on the rehabilitation of victims of the Boko Haram insurgency as $f$ $=1075.657$, therefore, $p=.000, p<.05$. This therefore means that reconstructive peacebuilding on its own has no significant impact on victims but when employed with transformative peacebuilding, a significant positive effect takes place (Egbusie, 2021). Since conflict is a socially constructed cultural event and people are active participants, it is therefore difficult for political level resolutions (reconstructive peacebuilding) to transform the conflict alone; hence, the need to go beyond that gamut. Going beyond reconstructive peacebuilding therefore entails employing both dimensions of peacebuilding - reconstructive and transformative.

\section{RECOMMENDATIONS}

Consequent upon the above, the following are suggested recommendations:

(i) More Emphasis on Transformative Peacbuilding
The approach of transformative peacebuilding aims at aiding sustainable development, growth and lasting peace both on an individual and societal basis by promoting reconciliation and nation (community) building. By emphasizing more on transformative peacebuilding, victims are not only physically healed, but are equally healed emotionally; as healing process originates from the internal and terminates externally. It is therefore pertinent that rather than governmental and nongovernmental agencies accentuate more on reconstructive peacebuilding and relegate the transformative dimension, transformative peacebuilding should equally be taken into consideration.

(ii) A Combination of Reconstructive and Transformative Peacbuilding

Neither of the peacebuilding processes could be regarded as irrelevant or inefficient. Both approaches to peacebuilding interact. This interaction is founded on the singular fact that conflicts are socially structured events with human beings as active participants in them. Since conflicts occur in a particular society or culture and man by his very own makeup is a social animal, it therefore means that none of these aspects of peacebuilding should be taken utilized in isolation of the other. Consequently, peacebuilders are encouraged to employ a combination of both reconstructive and transformative peacbuilding processes for an effective, efficient, pragmatic and better desired outcome.

\section{CONCLUSION}

Although the Boko Haram insurgency in Nigeria has spanned for over a decade claiming the lives of thousands and displacing people in their millions, the end of this ongoing battle against terrorism is much anticipated. What becomes the fate of those victims who have suffered both material and human loss? What emphasis are placed on not only the societal reconstruction and healing but also the transformation and healing of those injured, battered and scarred emotions? This thus is a call for all agencies involved in the peacebuilding process in the conflict-torn society of northeastern Nigeria to take a step further by going beyond reconstructive peacebuilding.

\section{REFERENCES}

[1] Abimbola Adesoji, The Boko Haram Uprising and Islamic Revivalism in Nigeria, Africa Spectrum, Vol.45, No.2 (August, 2010): 95-108.

[2] Adam Nossiter, Boko Haram Militants Suspected in Attacks at Mosques in Nigeria, The New York Times, $2^{\text {nd }}$ July, 2015. Retrieved 29.10.2021.

[3] Nurudeen Aderibigbe, Theories of Peace Education and Conflict, (Lagos: National Open University of Nigeria, 2010), 54-56.

[4] Joseph Adesina, Predicting the Effect of Counselling on the Psychological Adjustment of Book Haram Victims In Nigeria, International Journal of Arts And Humanities, Vol. 2, Iss. 4 (2013): 205-216.

[5] Al Jazeera English, Nigeria Killings Caught on Video - Africa, 10 February 2010. Retrieved 06.08.2021.

[6] Amnesty International, Nigeria 2020, Retrieved from www.amnesty.org/en/location/africa/west-and-centralafrica/nigeria/report-nigeria/ 29.10.2021. 
[7] Bayo Adekanye, Review Essay: Arms and Reconstruction in PostConflict Societies, Journal of Peace Research, Vol. 34, No. 3 (August, 1997):359 - 366.

[8] BBC News, Nigeria’s “Taliban” Enigma, 28 July 2009. Retrieved 01.08.2021.

[9] BBC, Nigeria Militants Burn To Death Motorists As They Sleep In Their Cars, Retrieved from www.bbc.com/news/world-africa, February 10, 2020. 29.10.2021.

[10] Boutros Ghali, An Agenda For Peace: Preventive Diplomacy, Peacemaking and Peace- Keeping Document A/47/227-S/241111 (New York: Department Of Public Information, United Nations (June 17, 1992).

[11] David Cook, The Rise of Boko Haram in Nigeria, Combating Terrorism Center, Vol. 4, Iss. 9 (September, 2011): 3.

[12] Duncan Gardham \& Laura Heaton, (25 Coordinated bomb attacks across Nigeria kill at least 40, The Telegraph Newspaper, (25 December, 2011), Retrieved August 2014.

[13] Emmanuel Aiyede, Theories in Conflict Management, (Lagos: National Open University of Nigeria, 2006), 57-58, 94-95.

[14] Evans-Kent Bronwyn, Reconstruction Over Transformation: The Structural Appropriation of Peacebuilding. (New York: Thames and Hudson, 2001), 2, 95

[15] Farouk Chothia, Who are Nigeria's Boko Haram Islamists? BBC News 11January, 2012. Retrieved 01.08.2021.

[16] Freedom Onuoha, Boko Haram and the Evolving Salafi Jihadist Threat in Nigeria, In Pérouse de Montclos, Marc-Antoine. Boko Haram: Islamism, politics, security and the state in Nigeria, (Leiden: African Studies Centre, 2014), 158-191.

[17] Ibrahim Mshelizza, Islamist Sect Boko Haram Claims Nigerian U.N. Bombing, Reuters (29 August, 2011).

[18] Isaac Albert, Introduction to Third Party Intervention in Community Conflicts, (Ibadan: PETRAF \& John Archers Publishers Ltd. 2001),61.

[19] Johan Galtung, Peace by Peaceful Means: Peace and Conflict, Development and Civilization, (London: Sage Publications, 1996), 70.

[20] John Paul Lederach, Preparing for Peace Conflict Transformation across Cultures, (Syracuse: University Press, 1995), 20.

[21] Joshua Bolarinwa, Introduction to Peace Studies, (Lagos: National Open University of Nigeria, 2006), 33

[22] Kunle Sani, 110 People Killed In Boko Haram Attack On Borno Farming Community - UN, Premium Times, $29^{\text {th }}$ November, 2020. Retrieved 29.10.2021.

[23] Mahatma Gandhi, The Mind of Mahatma Gandhi: Encyclopedia of Gandhi's Thoughts, $2^{\text {nd }}$ ed., (Ahmedabad: Navajivan Publishing House, 2007), 52.

[24] Martin Ewi, Why Nigeria Needs A Criminal Tribunal and Not Amnesty for Boko Haram, Institute for Security Studies, (Pretoria, 2013).

[25] Michael Diyoke \& Christopher Oguche, A Critical Appraisal of Boko-Haram Insurgency and the Criminal Topography of Sambisa Geosphere, International Journal of Academic Research in Business, Arts and Science, Vol. 1, Iss. 1, (August, 2019): 4.

[26] Monsuru Kasali, Concepts and Practice of Peacebuilding, (Lagos: National Open University of Nigeria, 2006), 150

[27] News Wires, Suspected Boko Haram Extremists Kill Dozens Of Nigeria Farmers, FRANCE 24, November 29, 2020. Retrieved 29.20.2021.

[28] Olalekan Adetayo, Boko Haram Has Infiltrated My Govt. Jonathan, The Punch Newspaper, (9 January, 2012). Retrieved 10 August 2021.

[29] Oluwatosin Babalola, Combating Violence Extremism and Insurgency in Nigeria, (Fort Leavenworth, KS: Foreign Military Studies Office, 2016), 4-5.

[30] Oyedolapo Durojaye, Understanding Peace and War, (Lagos: National Open University of Nigeria, 2010), 44-45.

[31] Philip Egbusie, Post-Conflict Reconstruction and the Mental Health of Victims of Armed Conflicts in Nigeria: A Study of the Boko Haram Insurgency, (2021, Unpublished): 202.
[32] Sabrina Ford, Laura Italiano \& Post Wires, Boko Haram Kidnaps More Children, Kills Villagers In Nigeria, New York Post, May 11, 2014. Retrieved 29.10.2021.

[33] Segun Mausi, Dispatches: What Really Happened in Baga, Nigeria? Human Rights Watch, 14 January 2015.

[34] Stephen Browne, Developing Capacity through Technical Cooperation: Country Experiences, (London: Earthscan, 2002), 24.

[35] The Guardian, Nigeria Accused of Ignoring Sect Warnings Before Wave of Killings (London: 2009) 2 August 2009. Retrieved 06.08.2021.

[36] The Independent, Nigeria Committing War Crimes To Defeat Boko Haram, 19 August 2014. Retrieved 06.08.2021.

[37] Tolu Ogunlesi, Nigeria's Internal Struggles, The New York Times, 23 March 2015. Retrieved 01.08.2021. 